\title{
41. A STUDY OF GEOPHYSICAL DATA ALONG THE DEEP SEA DRILLING PROJECT ACTIVE MARGIN TRANSECT OFF GUATEMALA ${ }^{1}$
}

\author{
Roland von Huene, U.S. Geological Survey, Menlo Park, California, \\ John Miller and David Taylor, U.S. Geological Survey, Denver, Colorado \\ and \\ Donna Blackman, U.S. Geological Survey, Menlo Park, California ${ }^{2}$
}

\section{INTRODUCTION}

Geophysical site survey data along the DSDP Middle America Trench transect off Guatemala (Ladd et al., 1982; von Huene et al., 1982) were augmented both before and after Leg 84 . Topography along the transect was detailed in two Seabeam surveys, the first by the Charcot (Aubouin, Stephan, Renard, et al., 1982) and the second by the Washington (T. H. Shipley et al., personal communication, 1983). Glomar Challenger also ran a grid of conventional bathymetric lines to extend the site survey data while waiting for permission to drill sites off Guatemala on Leg 84 . Seismic records along the main transect of the site survey were reprocessed using more advanced programs than those available during the original processing of the surveys. The original records were commonly obscured by diffractions (Ladd et al., 1982); by further processing, many of the diffractions were eliminated and tectonic features were more clearly imaged. Reported here is a study of these data and the resulting additions to the tectonic history of the Middle America Trench, particularly the development of the forearc basin, the front of the margin, and the origin of topographic steps near the base of the slope.

\section{TOPOGRAPHY IN THE TRANSECT AREA}

The topographic map along the transect was greatly improved by the two Seabeam surveys. The Seabeam maps were prepared at a $10-\mathrm{m}$ contour interval, and we combined them at a $100-\mathrm{m}$ contour interval to form the core of a new map (Fig. 1). Because the positioning of the Seabeam data was more accurate than the original site survey, the Seabeam data were used as a topographic reference to adjust the position of each conventional bathymetric line that crossed the Seabeam core. The Glomar Challenger grid of lines was controlled by satellite navigation with positions at roughly one-hour intervals, so not much adjustment was required. The original University of Texas data were controlled by far fewer positions, perhaps two or three per day. In our map (Fig. 1),

\footnotetext{
${ }^{1}$ von Huene, R., Aubouin, J., et al., Init. Repts. DSDP, 89: Washington (U.S. Govt. Printing Office).

Addresses: (von Huene and Blackman), U.S. Geological Survey, Menlo Park, CA 94025; (Miller and Taylor) U.S. Geological Survey, Denver, CO. (This chapter was prepared while von Huene was a visiting researcher, Laboratoire de Géologie Structurale, Université Pierre et Marie Curie, Académie de Paris.)
}

the Seabeam data are contoured with solid lines and the conventional sounding data with dashed lines.

The contours were then digitized and displayed through a computer program as perspective diagrams; examples are shown at two vertical exaggerations (Figs. 2 and 3). The major topographic elements are (1) the upper slope, which drops $1.5 \mathrm{~km}$ at a $12^{\circ}$ angle; (2) a midslope terrace, with a $2^{\circ}$ slope: (3) a $5^{\circ}$ lower slope: (4) and the Trench floor. Local benches mark the lower slope, and the Trench axis is adjacent to a relatively straight basal scarp.

The most prominent transverse feature of the shelf and slope is San José Canyon, which is $20 \mathrm{~km}$ wide and $1 \mathrm{~km}$ deep near the edge of the shelf. At the shelf edge the Canyon reaches a maximum depth of $1.8 \mathrm{~km}$. The gentle subdued canyon morphology on the shelf gives way to a v-shaped central erosional furrow as the canyon proceeds down the slope. Seismic records of the shelf show up to 1-km-thick channel fill in the upper smooth reaches of the Canyon and erosion of the fill by the v-shaped notch on the slope (von Huene et al., 1982; Ladd, this volume). On the lower slope, the channel exposes basement, as shown by drilling (Site 566 report) and seismic records 2, 7, and 10, (Ladd et al., 1982). The sharp v-shaped channel continues almost to the Trench, and is no longer detected as it crosses the lowest bench (Fig. 2) (McMillen et al., 1982). Although San José Canyon is the largest canyon crossing the slope, many other canyons are defined by the Seabeam and Seismic data. One prominent straight canyon runs subparallel to seismic line 18 about $2 \mathrm{~km}$ away (Fig. 1, abandoned canyon) and begins at the edge of the midslope terrace. If projected a short distance to the upper reaches of San José Canyon, it makes a straight course that avoids the sharp offset in the present course of San José Canyon. These features suggest that the former canyon may be an abandoned lower part of San José Canyon. Igneous basement rock was cored on the bank of this possibly abandoned canyon (von Huene, this volume).

The landward slope of the Middle America Trench off Guatemala was previously described as an upper and lower slope divided by a midslope terrace (von Huene et al., 1982). The lower slope has a hummocky morphology and is terminated at the Trench by a straight basal scarp. The basal scarp is generally $0.5 \mathrm{~km}$ high, has a $15^{\circ} \mathrm{dip}$, and a smooth surface but no resolvable slope 


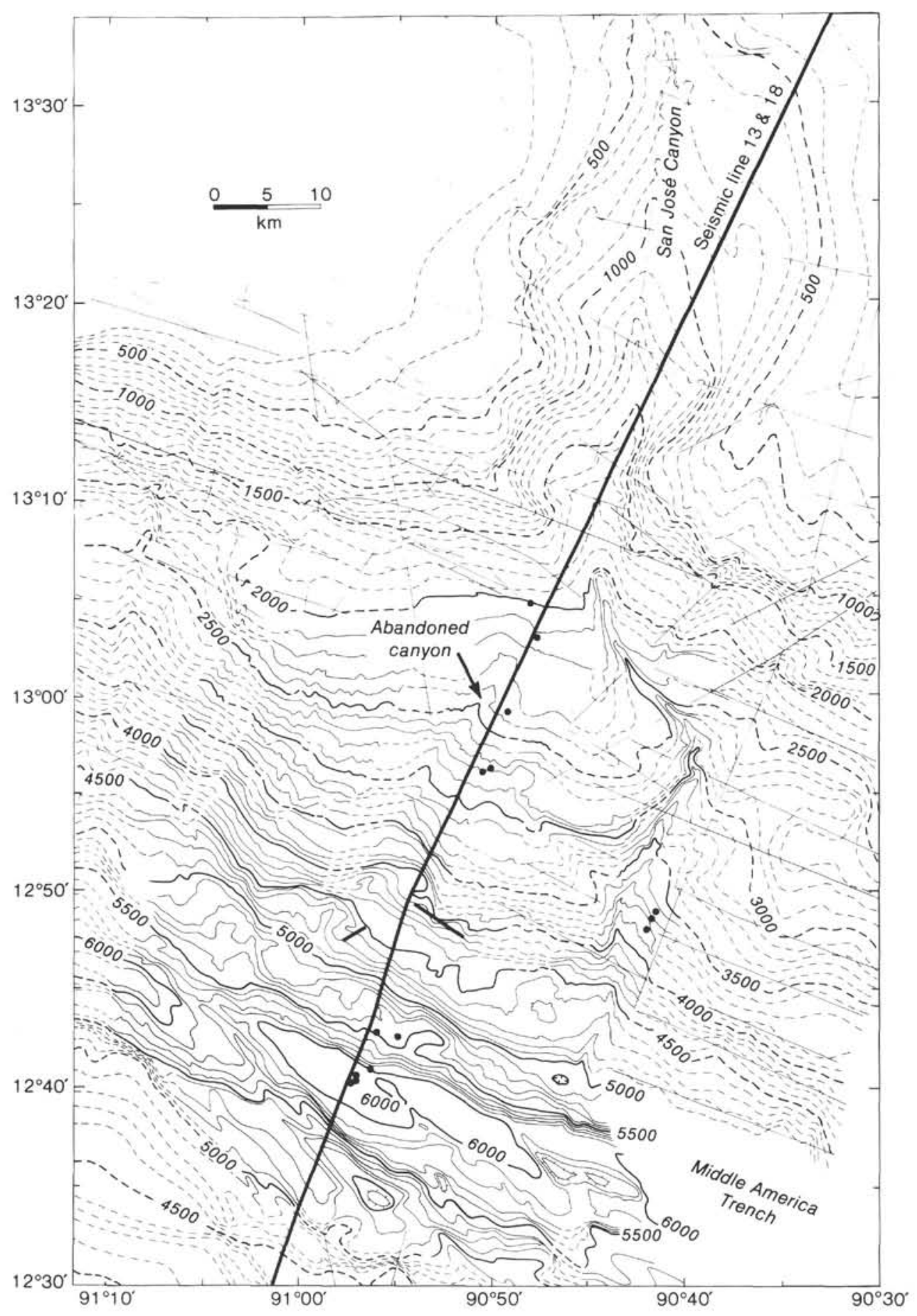

Figure 1. Topography across the DSDP Middle America Trench transect area. Contours, at $100-\mathrm{m}$ intervals, are solid where controlled by Seabeam data (Aubouin, Stephan, Renard, et al., 1982; T. H. Shipley et al., personal communication, 1983), and are dashed where controlled by conventional soundings. Lines are adjusted ships tracks of conventional data and the regular grid of tracks at the right margin are from the Glomar Challenger, made during a standby period. Conventional data positions were adjusted by fitting conventional bathymetric profiles to the Seabeam data in areas of overlap. The track through the center of the map is GUA-13 and-18, dots are DSDP drill sites, and lines are dredge tracks from the pre-drilling survey (see von Huene et al., this volume). 


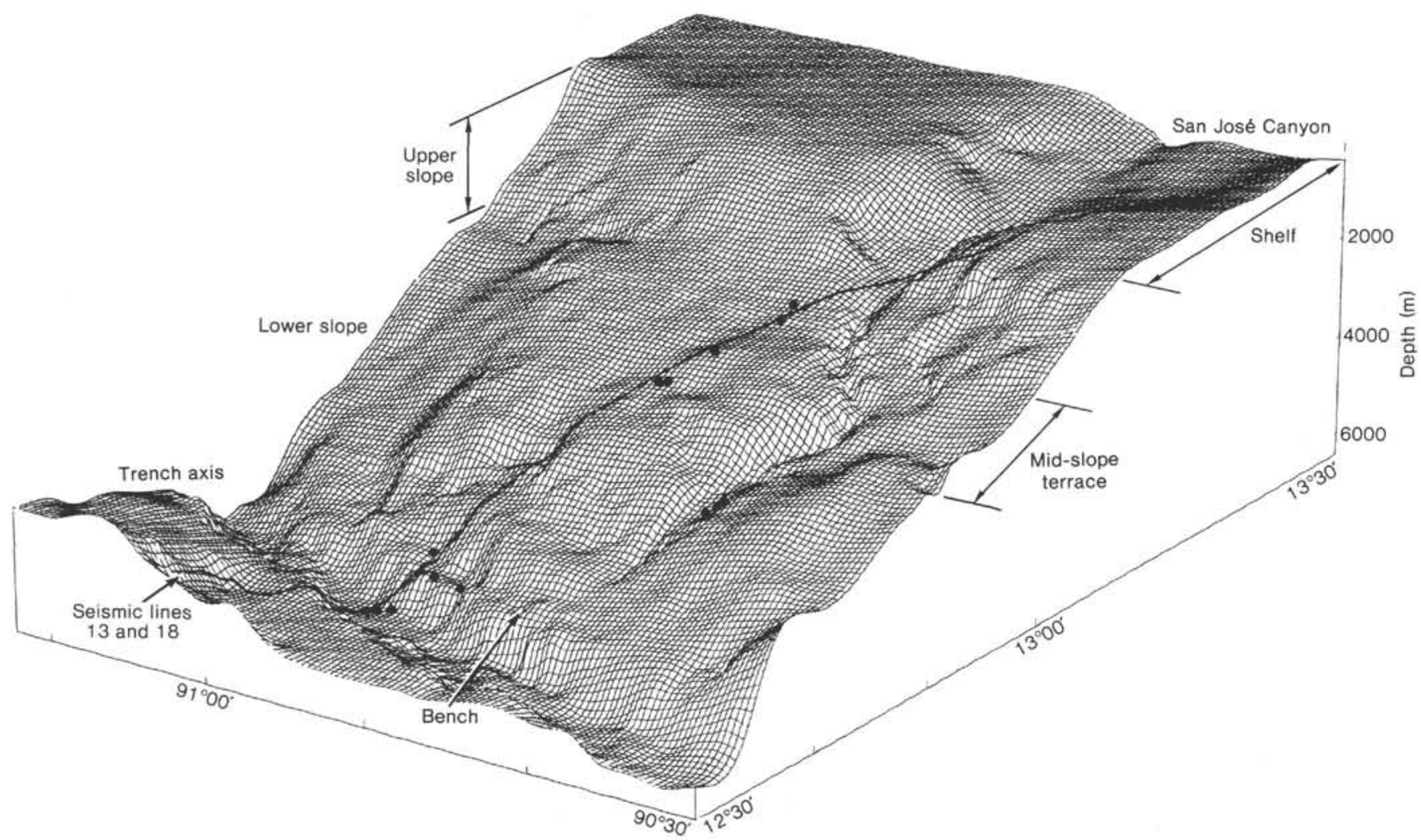

Figure 2. Perspective diagram of the bathymetry in Figure 1 at an exaggeration of $\times 7.5$.

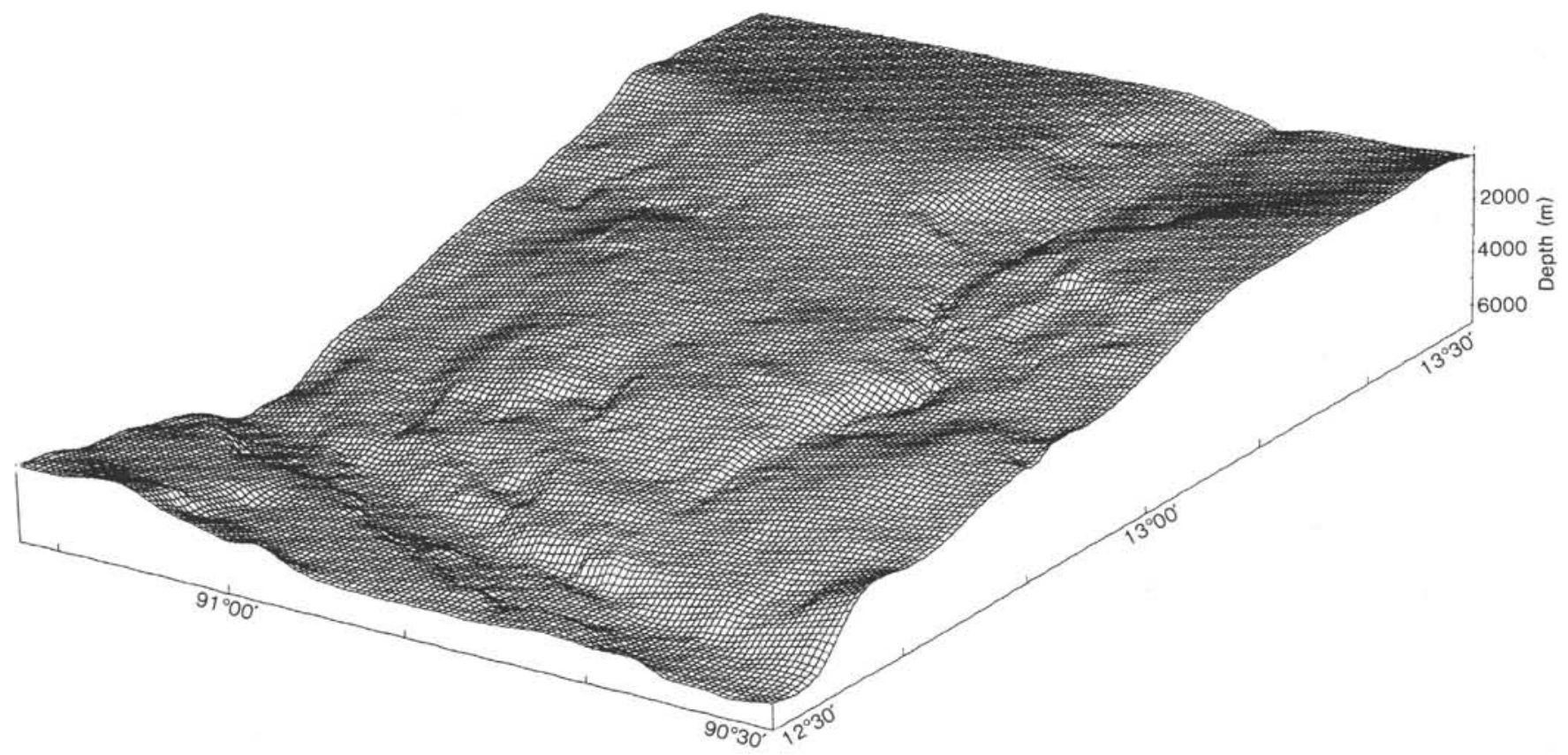

Figure 3. Perspective diagram of the bathymetry in Figure 1 at an exaggeration of $\times 3.5$.

cover in seismic or in deep-tow records (Moore et al., 1982). In the central part of the mapped area are two benches with bumpy irregular surfaces. The benches are bounded landward by steep scarps that are less linear than the basal scarp. The benches and bounding scarps fade out along either edge of the mapped area. They oc- cur in a rough but subdued lower slope reentrant best seen on the perspective diagrams (Figs. 2 and 3).

The reentrant and the benches have a morphology suggestive of a collapsed slope topography. The basal scarp has maintained its linear trace despite the subduction of the horst and graben topography on the ocean 
floor that trends $30^{\circ}$ from the trend of the scarp (Aubouin, Stephan, Renard, et al., 1982).

\section{REPROCESSING OF SEISMIC RECORDS}

The unexpected results of Legs 67 and 84 drilling stimulated a reexamination and reprocessing of the geophysical data from the University of Texas site survey reported previously by Ladd et al. (1982). It was desirable to sharpen the imaging of reflectors in the forearc section and the diffracted areas along some of the small faults. Ladd migrated sections of GUA-13 and -18 without much success, so it appeared that an extended careful effort would be required to improve the record quality significantly. This opinion was strengthened during attempts to migrate portions of records required for Leg 84 from the previously stacked data. The lower slope and Trench areas in line GUA-2 showed considerable improvement of surface detail as a result of migration, but the deeper section was degraded. Significant improvement appeared to require reprocessing from the field tapes rather than stacked tapes, and the Digicon DISCO facility at USGS in Denver provided improved capability over the older TEMPUS facility at the University of Texas in Galveston.

Two records were shot along the main traverse off Guatemala by the University of Texas. The first (in 1977) was GUA-13 (Ladd et al., 1982), which was selected for the main transect of Leg 67 drill holes. The University of Texas shot line GUA-18 during the next field season (in 1978) with a stronger Maxi-Pulse system rather than the 600-psi high-volume air guns used on GUA-13 (Ladd et al., 1982). However, the record of the outgoing signal required to deconvolve Maxi-Pulse was improperly recorded, and after deconvolution with another program, the resulting record was of similar quality to GUA- 13 . Because of its potentially greater energy and the improved system on which it was recorded, GUA-18 was selected for reprocessing, despite poor deconvolution.

The field tapes were demultiplexed and reedited. After velocity analysis and a reference NMO (normal move out) stack, the gathers were migrated. A second velocity analysis was made on the migrated gathers, using the semblance and the constant velocity methods. The migrated gathers were stacked using the revised velocities. In addition, the stacked but nonmigrated gathers were migrated for comparison. Record GUA-18A was migrated prior to stacking, NMO-corrected and stacked, and migrated a second time at a $1600 \mathrm{~m} / \mathrm{s}$ constant velocity (Back Pocket Plate I). The original tapes of record GUA$18 \mathrm{~B}$ were degraded from their condition five years earlier, because it was not possible to duplicate Ladds' results at the same level of processing even with the improved algorithms. Thus our results, particularly with GUA-18B, were less successful than we anticipated (Back Pocket Plate II).

The time sections were converted to depth using the refraction data of Ibrahim et al. (1979) and of Shor and Fisher (1961). Boundaries between velocity domains were made to change smoothly so as to avoid distortion (Fig. 4). The Shor and Fisher (1961) station is the landward-most refraction control, and it was projected into the reflection record as was done by Ibrahim et al. (1979), with the implication that the base of the sedimentary sequence corresponds to the boundary between the 4.4$\mathrm{km} / \mathrm{s}$ and $5.8-\mathrm{km} / \mathrm{s}$ layers. The resulting depth of the sediment in our depth section of GUA-18 is at $7.0 \mathrm{~km}$ at the intersection with Shor and Fisher line 4, whereas the corresponding refraction data are at $8.1 \mathrm{~km}$. Such an apparent discrepancy is an indication of uncertainties contributed by the averaging of the refraction record across the structure seen in the reflection record paralleling Shor and Fisher line 4 (GUA-33, Ladd, this volume). The reflection record shows a large basement high crossed by the refraction line, and where the refraction line crosses the seismic record of Seely (1979), the sediment sequence is much thinner and of lower velocity than at GUA-18. Thus the discrepancy between reflection and refraction data is probably not a mistake in calculation but the difference between local reflection and regionally averaged refraction measurements.

A sidelight of the comparison of reflection and refraction data is the indication of overlap in the velocities of the weathered ophiolitic rocks and the deep Cretaceous sediment. Prior to Leg 84, there was little indication from velocity data that the slope was formed of an ophiolitic sequence. In addition, magnetic anomalies gave no indication of igneous rock beneath the slope except near the shelf edge (Seely, 1979; Ladd et al., 1982). Comparison of GUA-18 and the refraction intercepts from - the University of Hawaii OBS network around Site 494 (Ambos and Hussong, this volume) indicates velocities as low as $3.4 \mathrm{~km} / \mathrm{s}$ in the top of the ophiolite sequence. In contrast are the indications of velocities as high as $4.4 \mathrm{~km} / \mathrm{s}$ in the deep portion of the sediment sequence, suggesting an overlap of $1 \mathrm{~km} / \mathrm{s}$ in the velocities of deep sedimentary and serpentinized ophiolitic rock.

\section{DESCRIPTION OF SEISMIC RECORD GUA-18A}

GUA-18 follows the upper course of San José Canyon across the shelf edge and then crosses the slope (Fig. 1). The landward part of the record, GUA-18A (Back Pocket Plate I), reveals more than $9 \mathrm{~km}$ of sediment beneath the shelf that thins to only about $5.5 \mathrm{~km}$ at the seaward edge of the shelf, just before the sediment sequence ends. On the slope, less than $1 \mathrm{~km}$ of sediment covers the igneous rock of the seaward extremity of the Central American continent.

The upper part of GUA-18A shows the fill in San José Canyon (Back Pocket Plate I, time section). Two sequences of canyon fill can be distinguished in the record: the lower, a wedge beginning at SP (Shot Point) 415 and extending seaward, is covered by the upper, which comprises the main body of canyon fill. The lower wedge appears to be guarded by a 1.8 -km-high bank cut by the Canyon. A period of rapid subareal erosion is not a likely explanation for this deep Canyon, because in the banks of the Canyon the Neogene section has no unconformities indicating a period of subaerial erosion. Thus we speculate that the depth of the Canyon resulted from a long period of submarine erosion, and perhaps repeat- 

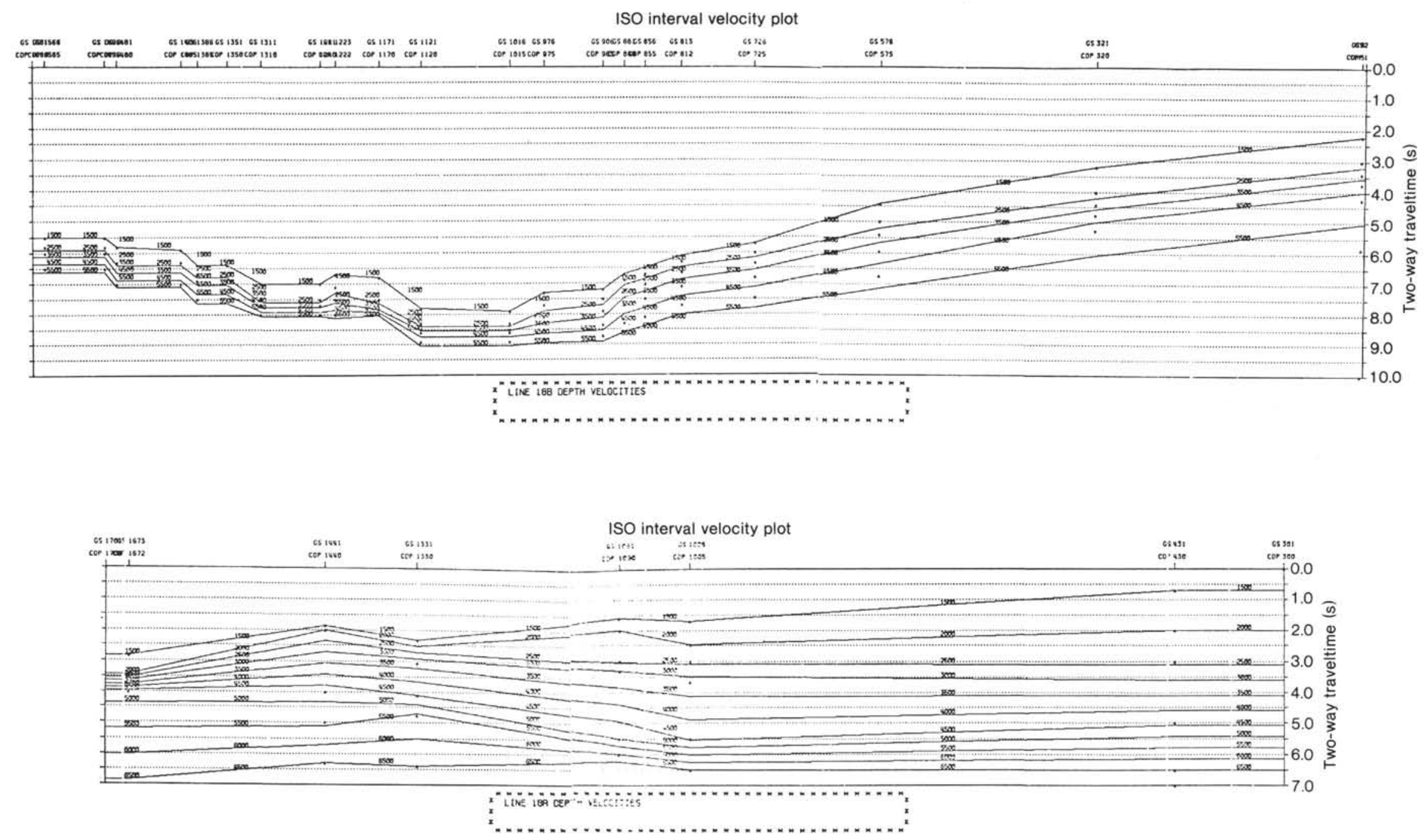

Figure 4. Velocity model used in converting GUA-18 to a depth section by computer. 
ed erosion and deposition of canyon fill has resulted from a history sufficiently long to span more than one major change in sea level.

Three of the time horizons traced by Ladd (this volume) through a network of seismic records from the ESSO Petrel drill hole (Seely, 1979) are used for temporal control here. The sediment sequence beneath the shelf is divided accordingly into a Neogene, an Oligocene-Eocene, a Paleocene, and an Upper Cretaceous and older (?) section.

The Neogene section has a generally less coherent reflective upper $1 \mathrm{~km}$ and uniformly well stratified lower $1.6 \mathrm{~km}$. The lower sequence thickens seaward about $20 \%$, but the seaward depocenter of the lower section has been eroded away during the time represented by the upper sequence. The upper sequence thins seaward, indicating a topographic high at the edge of the shelf. The base of the Neogene is conformable from SP 0 to 500 and unconformable from SP 500 to 760 , where it is truncated by erosion in San José Canyon.

The Eocene-Oligocene sequence contains single reflections continuous for $40-55 \mathrm{~km}$. These reflections pinch seaward just as the whole interval thins in a seaward direction, from a thickness of 5 to $2.5 \mathrm{~km}$. The Canyon has eroded the seaward end of the section. The depocenter of the Eocene-Oligocene basin was near the land- ward end of the record or about $20 \mathrm{~km}$ from the present coast.

In contrast to the Eocene-Oligocene section, the preEocene section does not thin much in a seaward direction in record $18 \mathrm{~A}$. It has a fairly uniform thickness of $2 \mathrm{~km}$, and from the segment in record 18A, not much can be said about the shape of the depositional basin except that it must have extended farther seaward than its present truncated seaward end.

Faulting is minor in the forearc sediment sequences considering the amount of convergence along the Middle America Trench. Four faults dipping steeply landward and one dipping seaward cut the pre-Miocene section (Fig. 5). The largest vertical displacement is $250 \mathrm{~m}$. There is no increase in faults toward the seaward end of the forearc basin. The horizontal stress from convergence is not evident across the shelf.

The pre-Eocene sediment sequence beneath the forearc basin ends around SP 1320 along a $45^{\circ}$ landwarddipping trend; the Eocene and younger section has been removed by erosion. Seaward of the truncation, stratified slope sediment rests on an "acoustic basement," which, in the reprocessed records, contains numerous faint coherent reflections. Deep in the "basement" is a sequence of strong landward-dipping reflections. These reflections correspond to the landward-dipping ones iden-
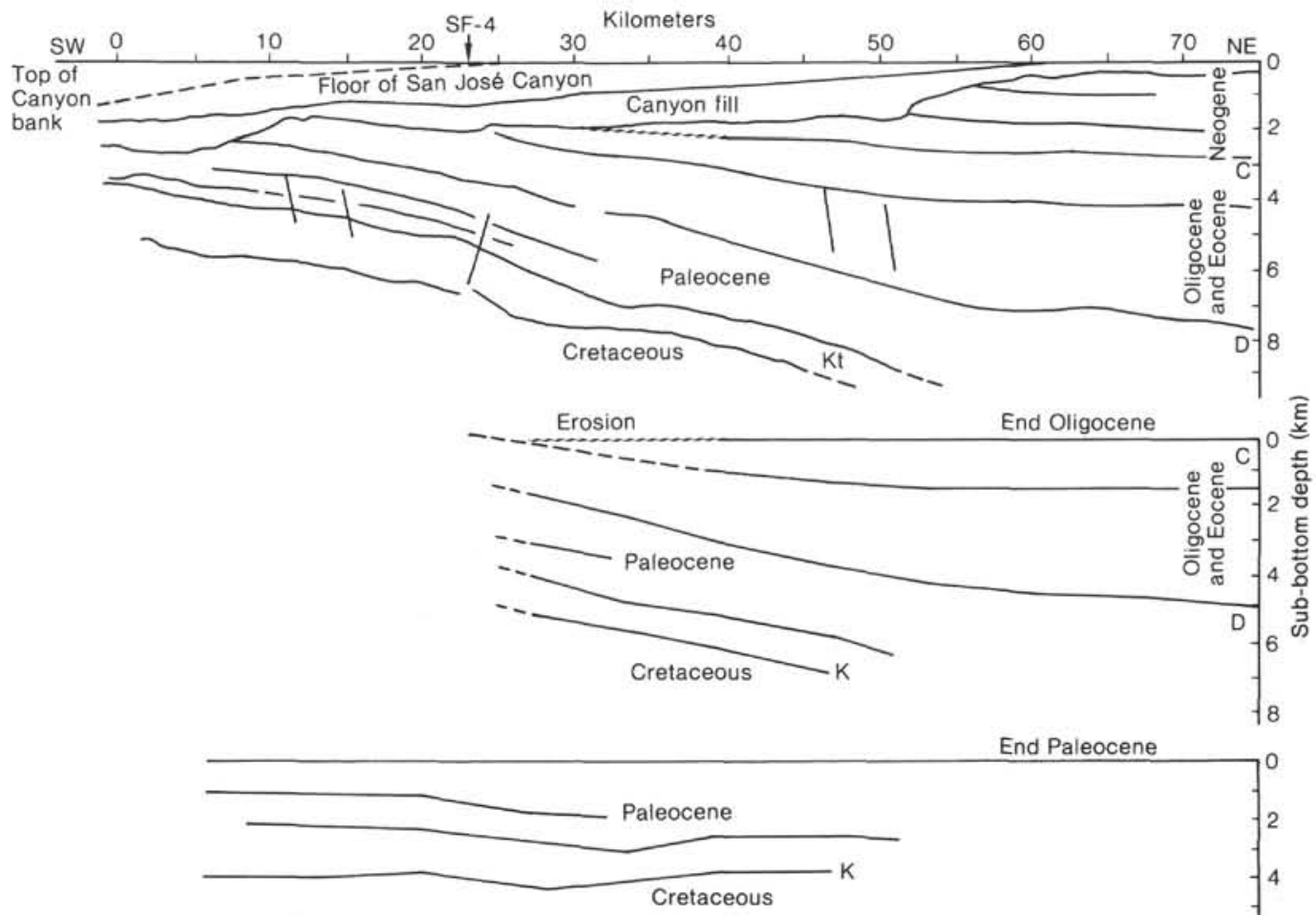

End Paleocene

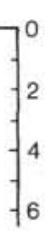

Figure 5. Paleoreconstruction of GUA-18A shelf sediment section. Each diagram represents the instant of time when the uppermost bed was being deposited, assuming that beds continuous over tens of kilometers were nearly horizontal when deposited. In GUA-18A reconstruction is severely limited by the erosion in San José Canyon and by the uncertain depths of beds at great depths in the landward part of the record. See text for explanation. $\mathrm{C}=$ base of the Miocene; D = base of the Eocene; $\mathrm{Kt}=$ top of the Cretaceous; $\mathrm{K}=$ approximate base of the sediment. SF-4 shows location of refraction line 4 of Shor and Fisher (1961). 
tified by Ladd et al. (1982) at this same position in record GUA-13. However, rather than being a single reflection extending from the surface, the migrated record indicates a packet of three reflections at depth. Thus despite refraction velocities from 4.5 to $4.8 \mathrm{~km} / \mathrm{s}$, the upper slope may contain either deformed and consolidated sediment or ophiolite.

The relative depth of basement between the end of the forearc basin and the beginning of the slope has much significance in regard to the tectonic history of this margin. If the forearc basin is underlain by pre-Late Cretaceous oceanic crust (Seely, 1979), the lowest reflection of the sediment sequence is the minimum depth to this old oceanic crust. Beneath the deposits of the adjacent slope the results of Leg 84 indicate ophiolite from pre-Late Cretaceous ocean crust (Site 570 report; Bourgois et al. and von Huene et al., this volume). If the area seaward of the clear reflections is considered to be composed of ophiolites because of its high refraction velocities, this limits interpretations. If the questionable area contains ophiolites, these ophiolites are 1.5 to $2 \mathrm{~km}$ shallower than the lowest reflection from a sedimentary bed in the forearc basin. Thus the vertical displacement of the forearc basin is down relative to the slope, which complicates interpretations of a thrust boundary at the end of the stratified sequence. However, the dip of such a boundary is unknown.

A paleoreconstruction was made of the sediment sequence beneath the forearc basin from the depth section of Back Pocket Plate I (Fig. 5). It was assumed that the beds continuous for 10 to $40 \mathrm{~km}$ were originally deposited in a nearby horizontal attitude. Thus when such a bed is rotated to horizontal and the overlying section is stripped off, it provides a picture of the basin at the time the horizon was deposited. Unfortunately, along GUA-18A much of the Eocene-Oligocene sequence was removed by erosion in San José Canyon. Also, below a depth of $9 \mathrm{~km}$, the reflections from the Cretaceous and Paleocene strata are not clear. However, the interpretation in Figure 5 shows that the Cretaceous and Paleocene sediment bodies are of relatively uniform thickness, and near the edge of the present shelf they were uplifted to form the Eocene-Oligocene basin. This same sequence of events was proposed from paleobathymetric studies by Seely (1979).

\section{GUA-18B, LOWER SLOPE, TRENCH, AND SEAWARD SLOPE}

The reprocessing of GUA-18B eliminated many of the diffractions and thus clarified structural relations in the record. Three displays were used most in the interpretation: (1) the migrated stacked data, (2) the data migrated before stacking, and (3) the migrated data converted to a depth section. Migration before stacking was a most successful technique for removing diffractions, as is illustrated along the seaward slope of the Trench (Back Pocket Plate II, time section). Seaward of the Trench the migration before stacking yields the best continuity of reflections and shows (1) small faults not visible in other displays, (2) a buried ridge in the Trench intercepted by drilling (Aubouin, von Huene et al., 1982;
Coulbourn, 1982), and (3) buried sediment horizons on the lower slope. The images of the fault scarps are surprisingly sharp considering the angle of roughly $35^{\circ}$ between the line of section and the trend of horst and graben on the oceanic plate (Aubouin, Stephan, Renard, et al., 1982).

On the landward slope of the Trench, reflections have been clarified considerably below the first bench. The cover of slope deposits can now be seen cropping out along the basal scarp (Back Pocket Plate II). Generally, however, the top $0.4 \mathrm{~s}$ of the record are not reflective, followed by a sequence of strong irregular reflections that probably mark the top of hard sediment and perhaps rubble from upslope. Below a rather noncoherent reflective section, weak coherent reflections (between 8.1 and $8.6 \mathrm{~s}$ ) are possibly from the sediment being subducted beneath the landward slope of the Trench. Sediment subduction is required here because no sediment has been accreted despite convergence at about $9 \mathrm{~cm} / \mathrm{yr}$., during the Neogene (von Huene and Aubouin, 1982; Aubouin, von Huene, et al; 1982).

Scarps of the landward slope have more irregularity than those of the seaward slope, and their structure is less clearly defined in the seismic record. Behind the first bench, the second scarp has some similarity with the faults of the seaward slope (SP 1350 and 1410). Some reflectors are truncated at the scarp, and others tend to follow the slope. Toward the back of the bench, reflections appear to be back-rotated.

Across the next bench the original data are degraded and little structure can be seen. The uppermost scarp has a strong reverberant sequence at the seafloor and possibly some truncation of reflections.

Along the landward part of the record, we had hoped to clarify the basement/slope sediment contact. The top of the ophiolitic basement was previously recognized as the uppermost highly diffracting, high-amplitide surface in a band of multiple overlapping diffractions (von Huene et al., 1982). Migration successfully collapsed the diffractions and left a band of short strong reflections. The basement surface must be rough. Within the slope deposits only local coherent areas can be seen. Poor coherency indicates poorly bedded sediment at the resolution of the seismic technique employed (about $50 \mathrm{~m}$ vertical).

\section{GUA-13, AIR GUN RECORD}

As noted previously, seismic record GUA-13 was shot using low-pressure, (600 psi) high-volume air guns, which produced a different type of seismic signal than the MaxiPulse. The processing sequences were similar; however, because of different source characteristics and some differences in position, the velocities were determined independently. Migration before stack was performed at a constant velocity of $1700 \mathrm{~m} / \mathrm{s}$. The reprocessing clarified details in the upper one second of the record (Back Pocket Plate III). The termination of bedding along the steps of the lower slope are clarified better than in GUA$18 \mathrm{~B}$ and show that strata in the slope deposits indeed end along the front of each step and are not folded under. The steps on the landward slope in GUA-13 have the same character as those on the seaward slope of the 
Trench in GUA-18B. Thus on the landward slope, seismic records and a morphology suggesting large-scale slope failure indicate a normal fault origin for the steps.

Reprocessing of GUA-13 also revealed faint indicators of stratification beneath the upper slope, as was noted for GUA-18A. The faint reflections are subparallel to the landward-dipping reflections of Ladd et al., (1982) and are truncated at the base of the slope strata. The basal slope strata appear to be little disrupted by faults, indicating major tilting of the strata prior to deposition of the slope sediment.

\section{REEXAMINATION OF THE SITE SURVEY GEOPHYSICAL DATA}

The insights gained from study of GUA- 18 and -13 and the results of Leg 84 led to reexamination of the original site survey data. The biostratigraphy of the forearc basin was known only from the published summary of a single industry drill hole and was tied to the unconformities of a seismic record (Seely, 1979); the sequence is not exposed along the coast of Guatemala. The base of the Miocene, the top of the Paleocene, and locally the top of the Cretaceous were traced both by us and by Ladd (this volume) through the network. These and other significant horizons were graphically converted from time to depth using a single average velocity model (Fig. 6) for simplicity in hand calculation. This method differs from the use of variable velocities in GUA-18, but does not greatly distort the general shapes of the sediment bodies. The general trend of thickness changes is shown at high vertical exaggeration in Figure 7, and the forearc sections are appended to the end of records previously converted to depth in von Huene et al., (1982).

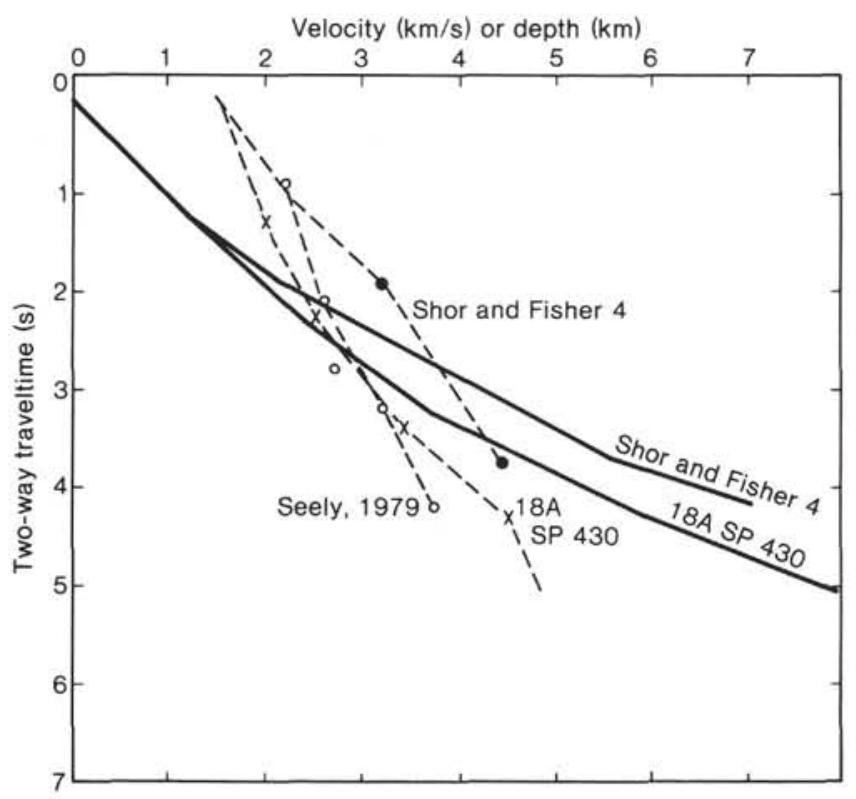

Figure 6. Time-velocity plots (solid lines) of refraction line 4 (Shor and Fisher, 1961), ESSO sonic log data (Seely, 1979), and interval velocities from stacking velocities at SP 430, GUA-18A. The timedepth relation (dashed line) was derived from the time-velocity data, and an average was used to construct the depth diagrams of Figures 6 through 12 .
The indications of uplift at the edge of the shelf seen in GUA-18 are also seen on other lines of the site survey. In depth sections (Fig. 7), it is clear that the main Neogene depocenter was near the Guatemalan coast in a position similar to the present one, and that the shelf edge was locally uplifted. Thus it appears that with the exception of periodic insular emergence at the edge of the shelf, the present environment represents the general Neogene environment across the shelf.

The Eocene-Oligocene sequence (C-D, Fig. 7) thins seaward, and the seaward edge of the basin is truncated. In the western part of the area, the Eocene-Oligocene sequence has been eroded to a depth of $1 \mathrm{~km}$ at the edge of the shelf along an early Miocene unconformity. Toward shore and in the eastern part of the area, the angular discordance disappears. The extent and depth of the early Miocene erosion is discussed in more detail further on.

The Paleocene commonly thins gently seaward and is distinguished by a more uniform thickness than the overlying units.

The base of the Upper Cretaceous (and perhaps older) section is best seen in the seaward part of the record published by Seely (1979) and in GUA-4 and -5 where the unit is thin. It was assumed that the Cretaceous section is underlain by oceanic crust (Seely, 1979, Ladd et al., 1982). If acoustic basement is assumed to be ophiolitic beneath the upper slope, the base of the sedimentary section is everywhere lower than the basement beneath the adjacent landward slope of the Trench (Fig. 7). The basement would thus be deeper beneath the forearc basin than it is beneath the slope, an important constraint in the interpretation of the tectonic boundary between the forearc basin and the slope of the Trench.

The basin shape changed between the Paleocene and the early Miocene during major uplift at the edge of the shelf and the development of the present arc-trench system, as was proposed by Seely (1979). A further study of the uplift was made by constructing isopach maps (Figs. 8 and 9) of the Paleocene and of the Eocene-Oligocene intervals using all of the seismic data in the area (Ladd, this volume). For convenience of calculation, the average velocity function (Fig. 6) was used. The Eocene-Oligocene sediment thickness indicates a depocenter landward of the site survey, and the contours trend subparallel to the edge of the present shelf (Fig. 8). The area eroded during the early Miocene is near the edge of the shelf and is localized west of San José Canyon. At the present head of San José Canyon about $5 \mathrm{~km}$ of sediment accumulated. The Eocene-Oligocene basin was flanked by a sharp structural high near the edge of the shelf, which is now partially missing.

Within the Eocene-Oligocene reflective sequence and concentrated on the seaward side of the basin are many continuous beds interspersed with a few local unconformities and pinching beds. At least some of the unconformity and irregular bedding seems associated with erosion of the edge of the shelf and deposition from a seaward sediment source. Records trending parallel to the strike of the basin show good continuous strata broken locally by channels. What remains of the eroded 


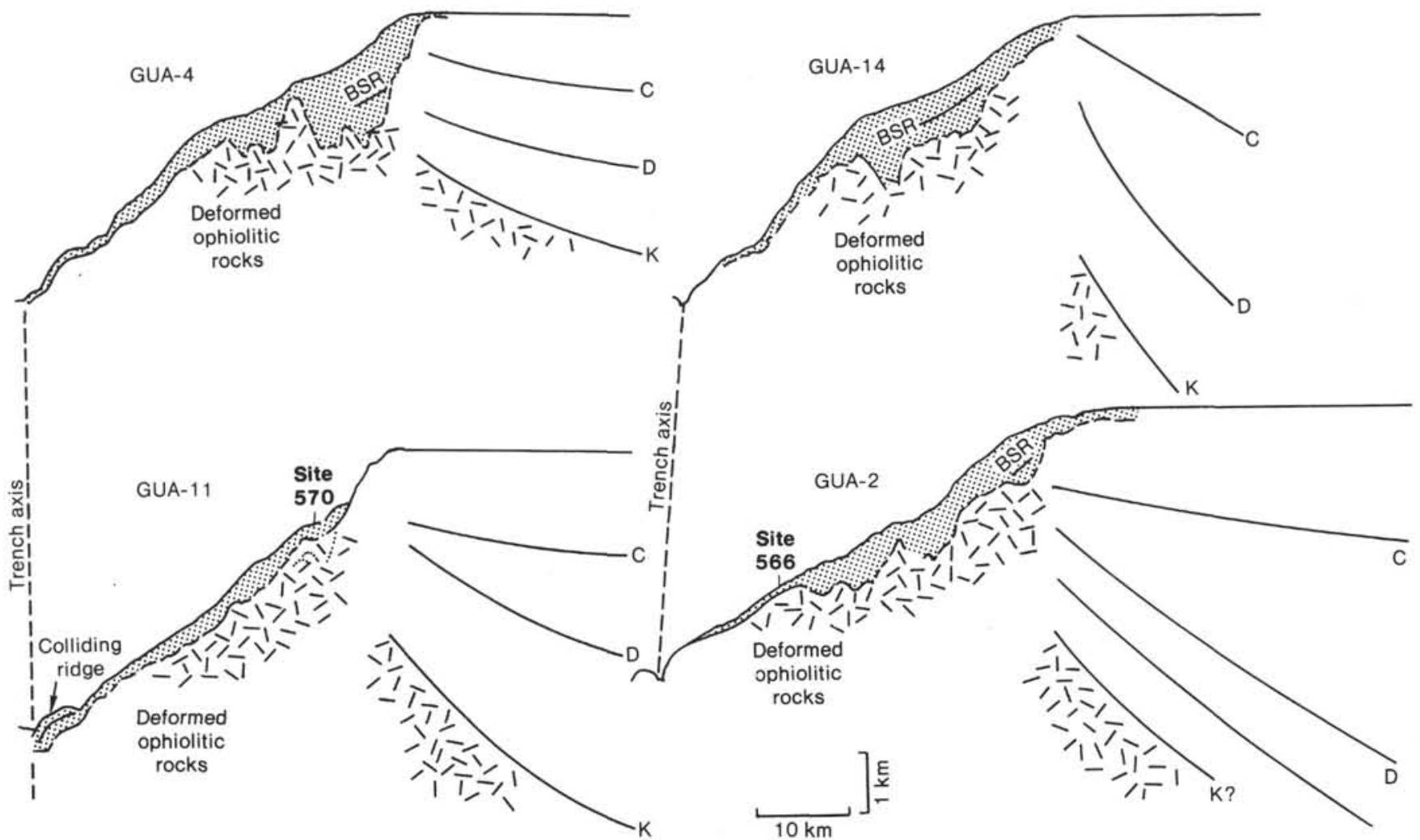

Figure 7. Diagrams at a high exaggeration of depth sections (vertical exaggeration $=\times 13.5$ ) made from seismic records of the site survey (Ladd et al., 1982). Data on the slope are from von Huene et al. (1982); depths in the shelf basin were developed using the velocity function in Figure 6, except at depths below $8 \mathrm{~km}$ where a constant velocity of $4.5 \mathrm{~km} / \mathrm{s}$ was used. $\mathrm{C}=$ base of the Miocene; $\mathrm{D}=$ base of the Eocene; $\mathrm{K}=$ approximate base of the sediment; BSR $=$ bottom simulating reflector.

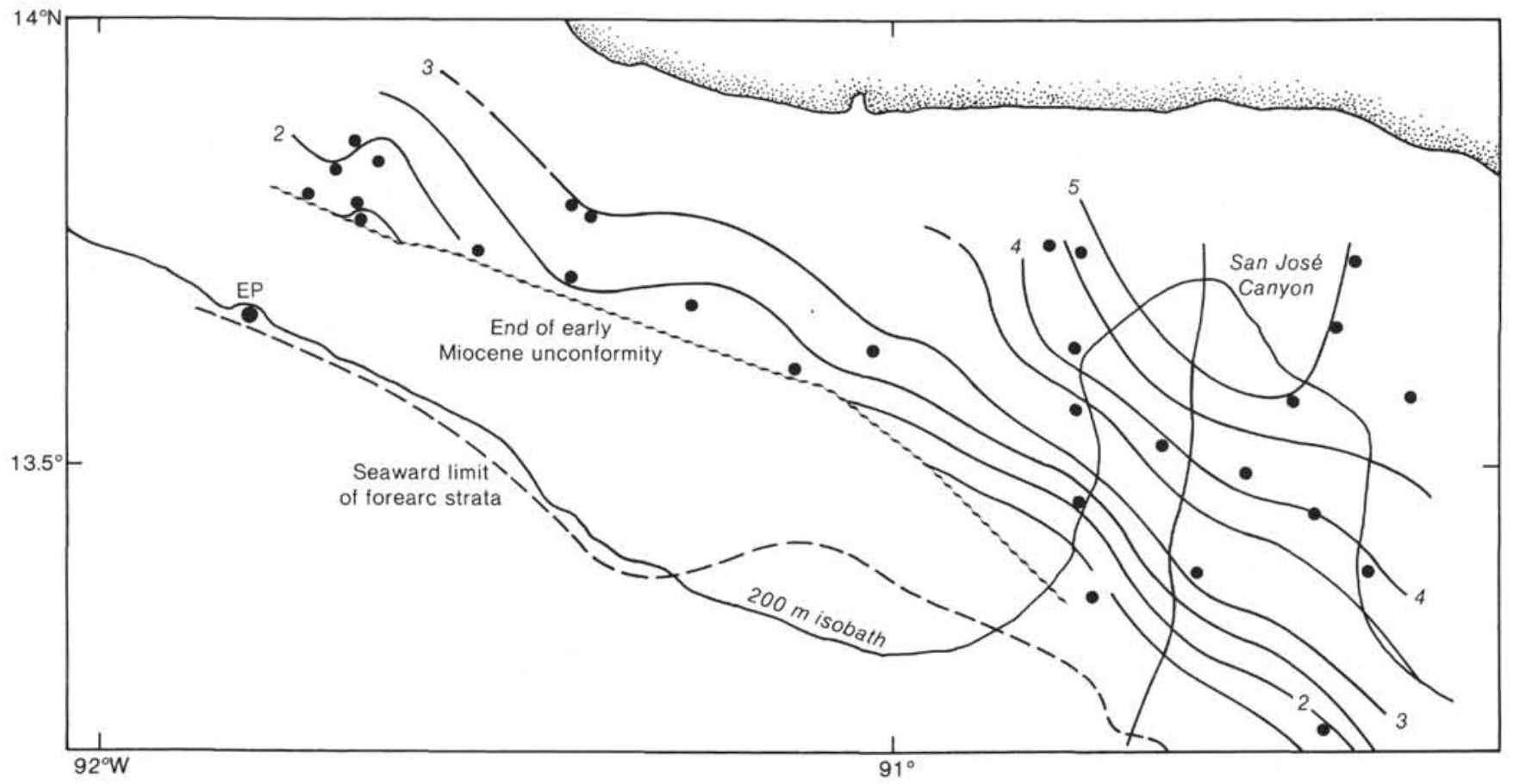

Figure 8. Isopach map of Eocene and Oligocene sediment. Contour interval $=0.5 \mathrm{~km} ; 200-\mathrm{m}$ isobath and the coast are shown for reference. EP is position of ESSO drill hole. Dots indicate points of control. 


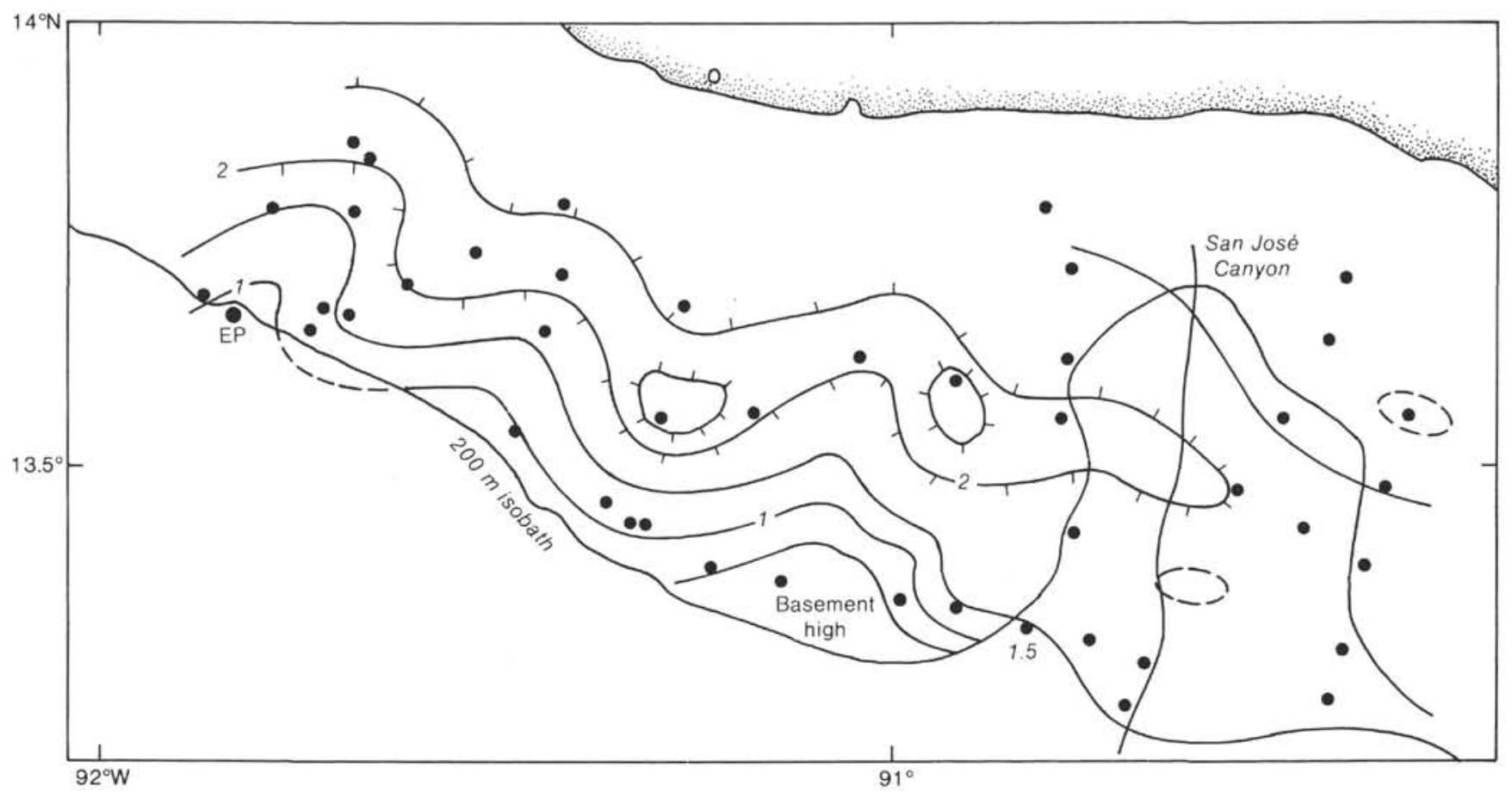

Figure 9. Isopach map of Paleocene sediment. Contour interval $=0.5 \mathrm{~km} ; 200-\mathrm{m}$ isobath and the coast are shown for reference. EP is position of ESSO drill hole.

area at the seaward edge of the forearc basin is up to $35 \mathrm{~km}$ wide.

The isopach map of the Paleocene section has shallower gradients in contrast to the Eocene-Oligocene section, and the thickest sediment is in a mid-shelf rather than a near-coastal position. The seaward termination of the Paleocene section is not linear as though faulted and without indication of containment behind a seaward structural high. Again, the eastern and western sediment bodies have somewhat different shapes. In the western part, the Paleocene laps onto the Cretaceous from a seaward direction, but otherwise there is little angular discordance between them. Records across strike show rare local unconformities and possible lensing. The isopach map and reflective sequence suggest a series of low fanlike bodies with occasional channels. The Paleocene unit thins gently in a seaward direction, indicating a landward source area.

The isopach maps show the change in basin configuration in response to the regional tectonism that marked initiation of the present arc-trench system. For further paleoreconstruction, a line from either end of the site survey was chosen to represent the two structural end members. Records GUA-2 and GUA-4 were plotted in depth at a vertical exaggeration of about $\times 3$ (Figs. 10 and 11). Then a reconstruction was made assuming, as before, that a sequence of parallel reflectors $10 \mathrm{~km}$ and more long were probably deposited in a near-horizontal attitude.

The sequence of diagrams for GUA-2 (Fig. 10) were relatively simple to construct, because the record contains no large angular unconformities. Along GUA-2 the base of the Neogene section is only about $1 \mathrm{~km}$ deeper near the depocenter than at the present shelf edge. Thus the underlying beds are rotated only slightly by the reconstruction back to the early Miocene. The EoceneOligocene section thickens about $5 \mathrm{~km}$ from the shelf edge to the middle of the basin; thus the rotation resulting from stripping of the Eocene-Oligocene section is considerable. The remaining Paleocene sediment body thins seaward at a far less rapid rate than the EoceneOligocene basin, and its possible seaward extension was estimated by projecting the upper and lower boundaries. Perhaps as much as 10 to $20 \mathrm{~km}$ of the front of the Paleocene basin is now missing.

The sequence of diagrams for GUA-4 (Fig. 11) is complicated by two profound angular unconformities and by the fact that only the seawardmost $30 \mathrm{~km}$ of the forearc basin were surveyed. Again, there are few changes in basin configuration when the Neogene basin is stripped away, but erosion at the edge of the shelf has removed much of the uplifted end of the forearc basin. By rotating a sequence of reflections within the Eocene-Oligocene section, the relative uplift at the edge of the shelf becomes clearer. Uplift appears to have been a gradual late Paleocene to late Oligocene event. The underlying $\mathrm{Pa}$ leocene body is of relatively uniform thickness and may have extended farther seaward than the uniformly thick Cretaceous sediment body. The present forearc basin was configured in the late Paleogene and has remained much the same through most of the Neogene.

\section{DISCUSSION}

Our diagrams of the progressive development of the forearc are not tied to absolute water depths except at erosional unconformities. We now use the benthic paleontology from the ESSO Petrel drill hole summarized by Seely (1979) to develop a tectonic history. With only 


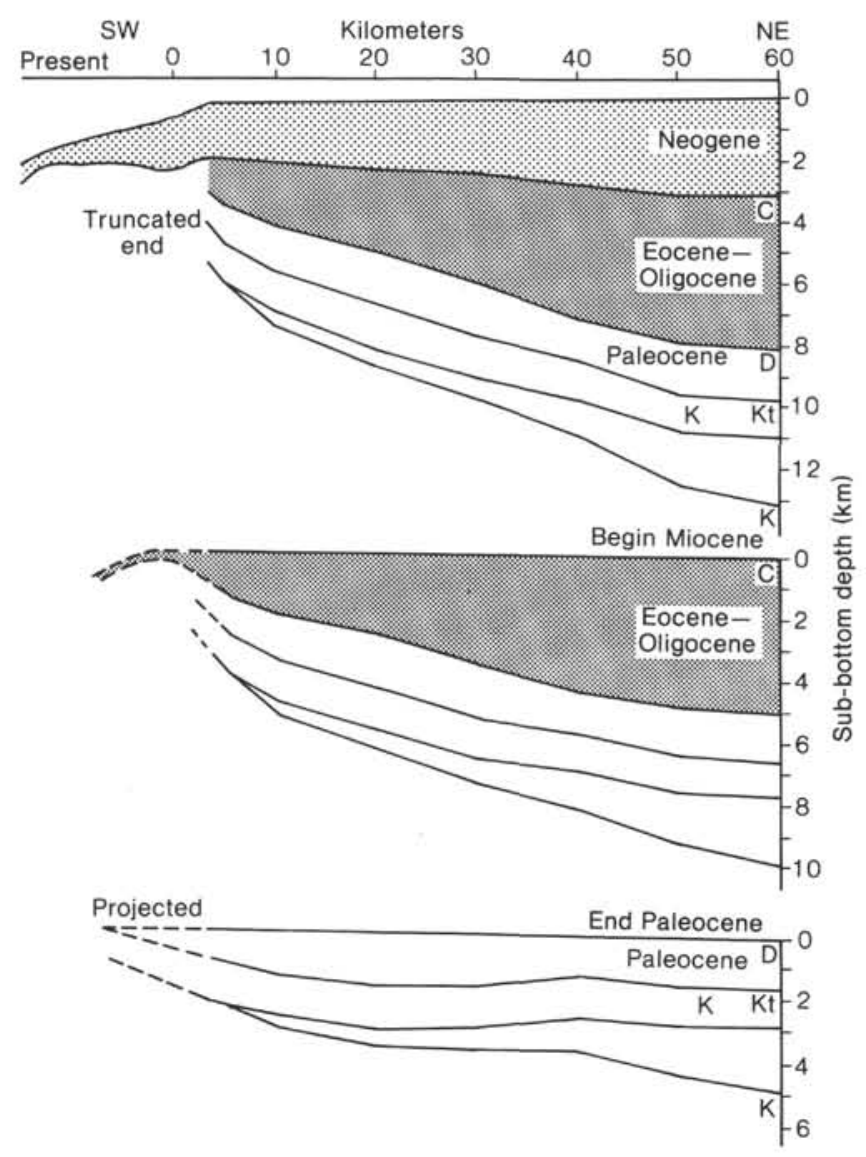

Figure 10. Graphic depth diagram of the forearc and pre-forearc sediment sections in GUA-2 plotted at a vertical exaggeration of about $\times 3$. Below the present-day depth diagram are reconstructions made as was done with GUA-18A. C = base of the Miocene; D = base of the Eocene; $\mathrm{Kt}=$ top of the Cretaceous; $\mathrm{K}=$ approximate base of sediment.

a single drill hole in the forearc basin and underlying sequence, we can only project a single benthic paleontology throughout the network of seismic lines across the shelf.

The tectonic history diagram of Seely (1979) is based on a study of benthic microfossils that is more than 10 years old. In the past decade, the techniques for determining depth from studies of benthic foraminifers have advanced. The depths of microfossil zones shown by Seely are shallower than those used by McDougall in her study of Leg 84 materials (McDougall, this volume), and the two studies need to be normalized to a common depth zonation. Faunal lists are not available to adjust the depths used by Seely in his analysis. His depths can be redefined, but with less confidence, by applying the depth limits used by McDougall to the named zones of Seely (1979). This results in a much slower rate of uplift than implied by Seely (1979).

The Paleocene-Cretaceous sediment from the ESSO Petrel hole contains microfossils that lived below the lysocline (greater than $3000 \mathrm{~m}$ deep). When we rotated this sequence to its original position and stripped off the overlying units, the Cretaceous-Paleocene interval showed a gentle seaward thinning. The $60-\mathrm{km}$ portion of the sequence shown in GUA-2 (Fig. 10) records only its partial width, from simple projection, the sequence appears to have extended landward at least to the present coastal plain, a distance of more than $20 \mathrm{~km}$. The seaward end of the Cretaceous-Paleocene units is missing, and by projection it appears that about 10 to $20 \mathrm{~km}$ has been removed. Thus the sediment body must have been about $100 \mathrm{~km}$ wide. Seely suggests that these sediments were deposited on an abyssal plain or in a trench. We favor deposition on an abyssal plain near the base of a slope because of the terrigeneous rates of sediment accumulation (ca. $170 \mathrm{~m} / \mathrm{m}$.y., as derived from the tectonic history diagram of Seely), the planar shape of the body, and its approximately $100-\mathrm{km}$ width, which is well in excess of most undeformed trench-filling sediment bodies. The configuration of the lowest body in GUA-4 (Fig. 11) suggests a turbidite filling of local pockets in an irregular topography of the igneous ocean crust.

The shapes of the Eocene-Oligocene bodies record the uplift of the front of the margin. The tectonic history diagram of Seely (1979) is diagramed to show a very rapid uplift at the end of the Paleocene, but in his discussion Seely implies a much slower rate. If Seely's data are adjusted to McDougall's depth zonation, uplift in the Paleocene was a minimum of 300 to $700 \mathrm{~m}$. Our graphic reconstruction (Figs. 10 and 11) suggests a progressive Eocene-Oligocene uplift, especially in records of the southeast part of the area. The wedging out of beds seaward throughout most of the Eocene-Oligocene section indicates uplift over much of that period.

A well-defined forearc basin had developed by the beginning of the Neogene. The benthic assemblages in the Neogene were deposited in middle to upper bathyal depths, and uplift continued at the present shelf edge as the basin was loaded with sediment (Seely, 1979). The erosion of Neogene beds at the edge of the shelf was probably caused by the combined effects of tectonic uplift and a drop in sea level, perhaps in the late Oligocene and early Miocene periods of lowered sea level. During the Oligocene and the Neogene, sites on the slope of the Trench were at abyssal depths (greater than $3500 \mathrm{~m}$ ), until the end of the Neogene when Sites 570 (Leg 84) and 496, and 497 (Leg 67) rose to bathyal depths (McDougall, this volume).

In summary, we have extended our study over a wider area than did Seely (1979) and find that our respective interpretations in the forearc area are similar. However, the discovery of Cretaceous ophiolites, cherts, and limestone covered by Eocene and younger slope sediment at the front of the margin (Aubouin, von Huene, et al., 1982) provides different constraints at the front of the margin than were available to Seely. In constructing a tectonic history, the two end-member interpretations of the upper slope in seismic records provides two limiting cases. If the faint stratification beneath the upper slope is inferred to be the imbricated missing frontal part of the Cretaceous and Paleocene base of slope sediment aprons, a history dominated by thrusting can be postulated. However, if the upper slope is inferred to consist mainly of ophiolitic rock, as might be implied from the ophiolite recovered at Site 570, a period dominated by 

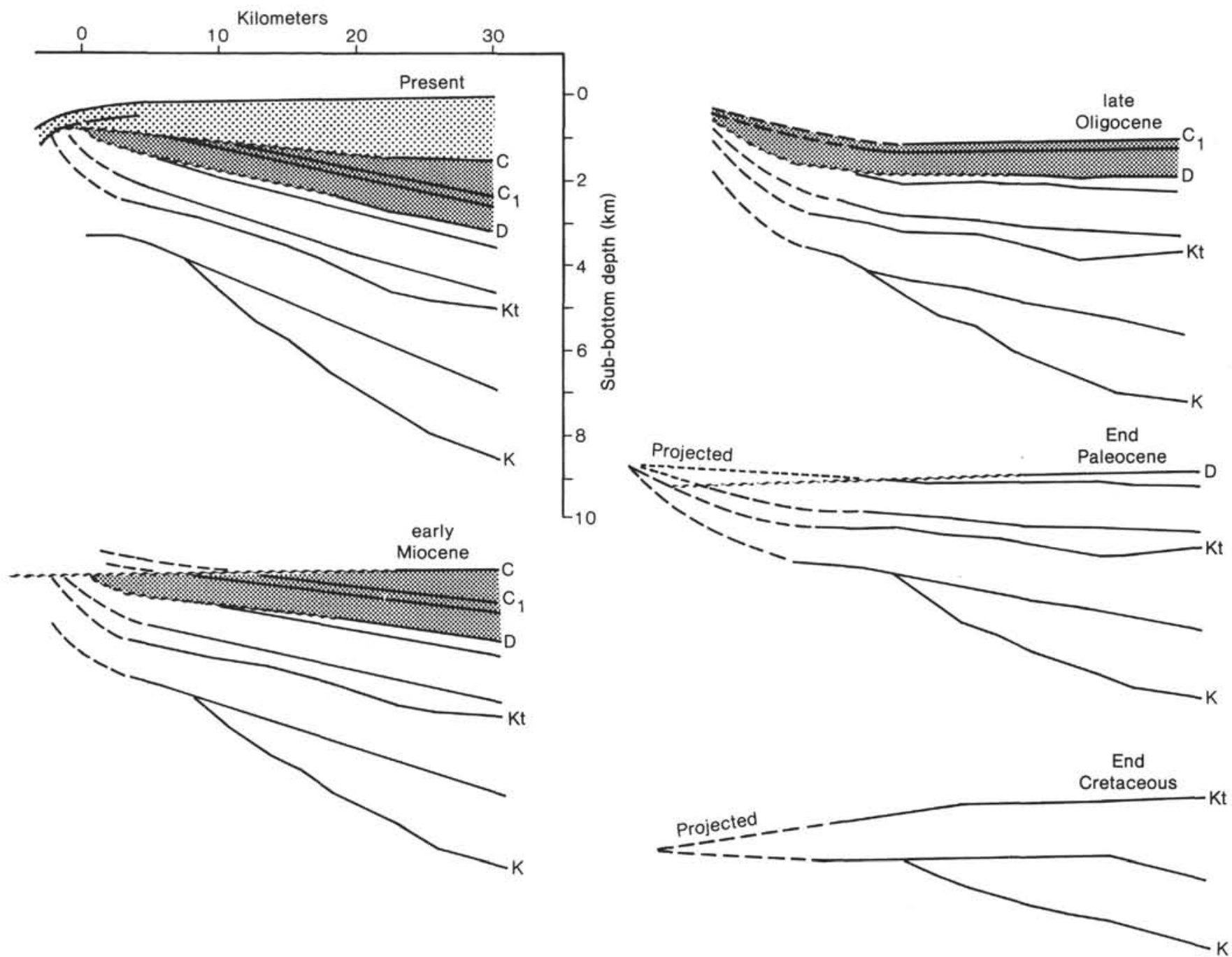

Figure 11. Graphic depth diagram of the forearc and pre-forearc sediment section in GUA-4 plotted at a vertical exaggeration of about $\times 3$. Following the depth diagram are reconstructions. Letter symbols represent same horizons as in previous figure; vertical scale is the same in all diagrams.

transform faulting may have preceded development of the Middle America Trench. Such a mechanism is required by the relation of the ophiolite beneath the upper slope to the presumed oceanic basement beneath the thick sediment beneath the shelf. The oceanic basement could be as much as $2 \mathrm{~km}$ deeper beneath the forearc basin than beneath the slope. Thus the fault following the landward-dipping reflectors in GUA-13 (Ladd et al., 1982) would have the displacement geometry of a normal fault. A hypothetical seaward-dipping thrust fault in front of the forearc basin along which ophiolites of the slope could be obducted and thrust over the seaward continuation of the Cretaceous-Paleocene sediment would tend to depress rather than uplift the front of the forearc basin. The essentially undeformed forearc basin sediment sequence argues against such obduction.

Another observation that must be explained is the contrast between the Cretaceous-Paleocene sediment beneath the forearc basin and that beneath the slope. Beneath the forearc basin, Cretaceous sediment from a terrigenous source was deposited in a $100-\mathrm{km}$-wide body, whereas the Cretaceous sediment from the slope is a limestone deposited in oceanic conditions away from terrigenous sources of sediment (von Huene, Friesen, and Blome; and McDougall, this volume). The Paleocene sediment beneath the forearc basin is more than $1 \mathrm{~km}$ thick and was also deposited in a $100 \mathrm{~km}$-wide body; no Paleocene sediment was recovered from the slope. The few tens of meters of Eocene and Oligocene sediment recovered on the slope are much thinner than the 1.5- to $5-\mathrm{km}$-thick section beneath the forearc basin. This sediment might be the distal equivalent of the thick coeval sequence in the forearc basin. Thus it appears that the Cretaceous and Paleocene sediments beneath the forearc basin and beneath the slope were deposited in environments formerly more distant from each other than now. The Eocene and Oligocene sediments are different on either side of the shelf edge but have character that might be consistent with their present forearc and slope settings.

We present a model of a sequence of events involving only convergence (Fig 12A) and compare it with one involving some transverse faulting (Fig. 12B). The convergent history in Figure 12A begins with the development 
A
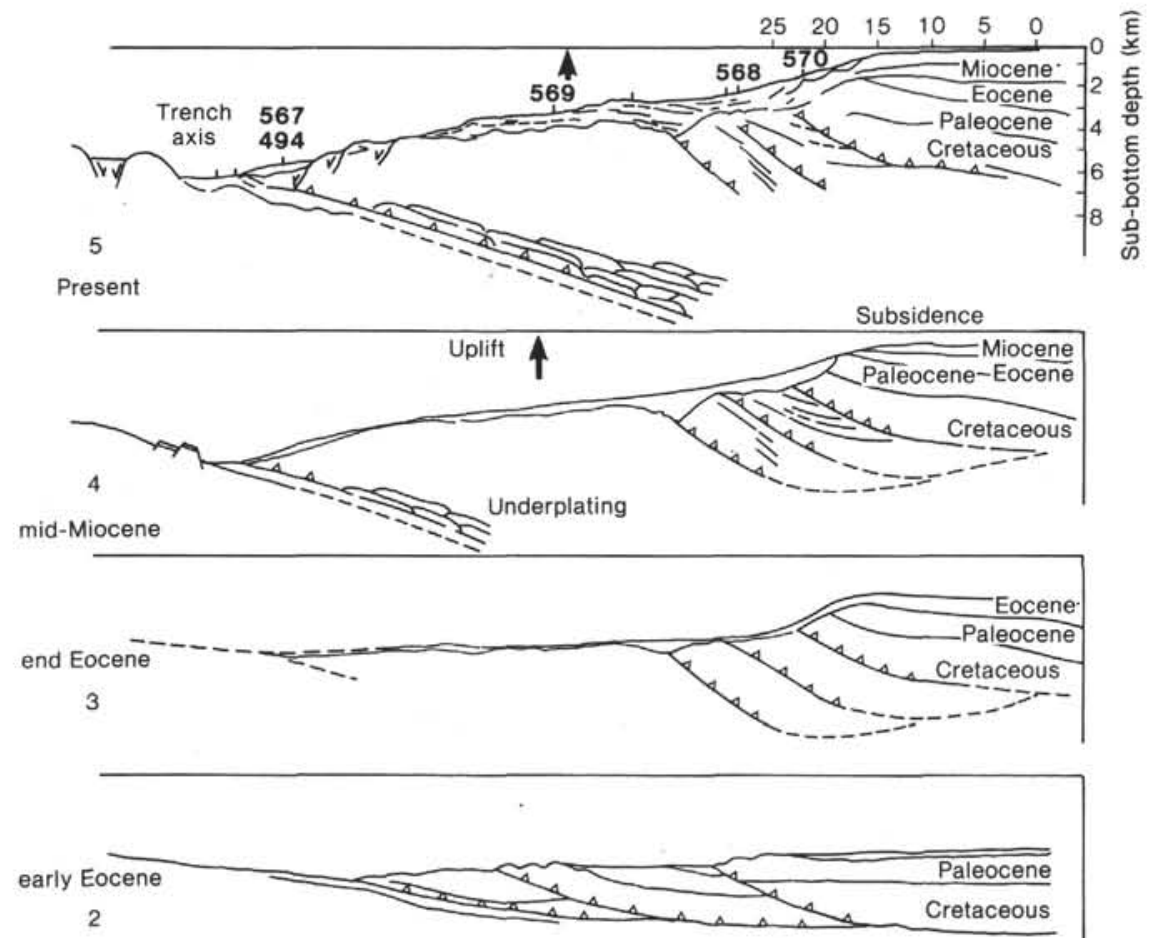

2$$
1
$$

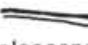

end Paleocene

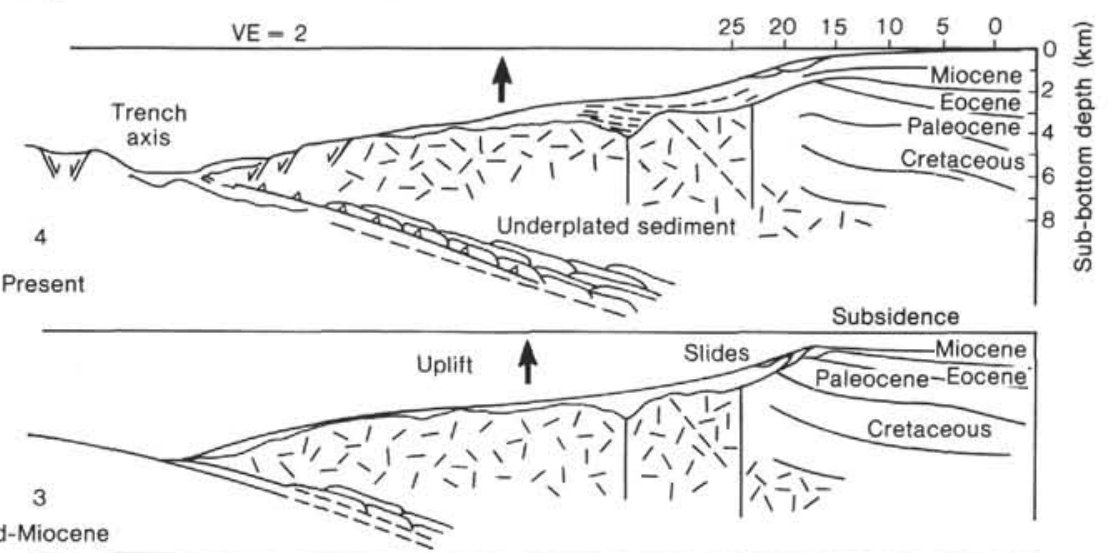

mid-Miocene

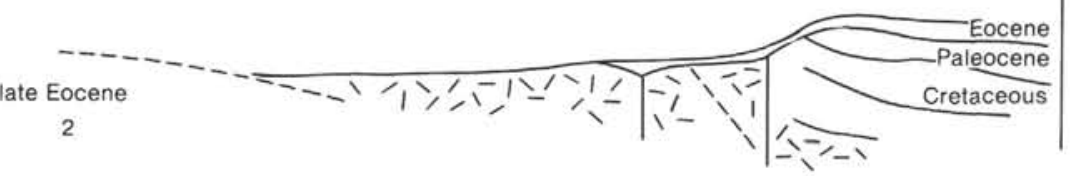

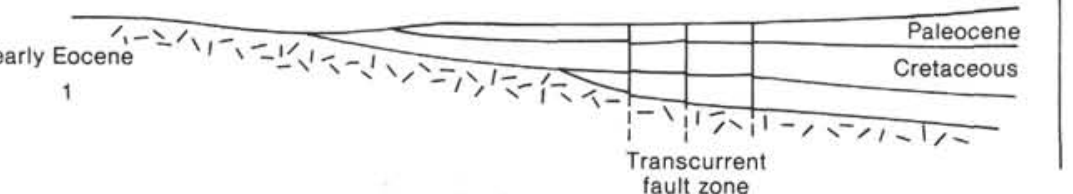

Figure 12. A and B. Diagrams illustrating speculative tectonic histories for the transect area. Both models use the paleobathymetry of McDougall and a paleobathymetry for the ESSO Petrel well, modified in accordance with the benthic foraminiferal zones used by McDougall. Model A is based on an interpretation of weak reflections in seismic records to indicate stratified rock. The model predicts about $40 \mathrm{~km}$ shortening during accretion of a base of slope sediment sequence. Model B is based on interpretation that disregards the weak reflections but emphasizes the recovery of ophiolitic rock (Site 570) on the upper slope. Two disparate terranes are juxtaposed by transcurrent faulting prior to a dominantly convergent tectonic regime. 
of a subduction zone beneath the front of a $100-\mathrm{km}$ wide Cretaceous and Paleocene sediment body at the base of a continental slope (Fig. 12A, 1 and 2). Between the end of the Paleocene and the late Eocene, the base of slope section was telescoped about $40 \mathrm{~km}$, juxtaposing an open ocean environment against the truncated edge of the base of slope sediment sequence (Fig. 12A, $3)$. After Eocene accretion, subduction cannot have involved any further net accretion because no Oligocene and younger accreted sediment is known. At the end of the Eocene the subduction zone jumped seaward, and the uplift of the area presently at the edge of the shelf continued by underplating (Fig. 12A, 4). The forearc basin subsided simultaneously as it accumulated thick sediment sequences (Fig. 12A, 4 and 5).

In the second model (Fig. 12B), we speculate that a zone of transverse faulting, which may have been associated or parallel with the ancient Polochic-Montagua system (Anderson and Schmidt, 1983), truncated the front of the Cretaceous-Paleocene sediment sequence and deformed the rock now beneath the midslope. Transform faulting at the end of the Paleocene (Fig. 12B, 1) and beginning of the Eocene may have brought the open ocean Cretaceous rock against the base of slope sediment sequence (Fig. 12B, 2). This transverse fault then became a subduction zone, and the upper plate was uplifted during the latter part of the Eocene and beginning of the Oligocene to form the present forearc basin (Fig. 12B, 3). A transcurrent fault helps explain the broad zone of deformation in the basement the midslope area where the topography is less steep (Figs. 2, 3, and 7). The continued Neogene uplift of the edge of the shelf was probably accomplished by faults along the upper slope. This caused the upper slope to become steep, to fail, and thereby erode the front of the forearc basin and underlying sediment sequence. The evidence for failure of the edge of the shelf is the disorganized reflections there and along the upper slope (von Huene et al., 1982).

On the lower slope, collapse is indicated by the topographic benches and termination of reflections in the seismic records along the DSDP transect (Figs. 2 and 3; Back Pocket Plates II and III). Collapse and normal faulting were previously emphasized by Aubouin, Stephan, Renard, et al., (1982) and Aubouin et al., (1984). The cause of the collapse above a subduction zone is likely to be associated with decoupling by elevated pore pressure (von Huene, this volume) and with the highly serpentinized rock of the slope. Overpressure decreases the strength of the rock and reduces friction along slip surfaces. Serpentine is inherently weak and is prone to failure, as exemplified by slope failures in the urban areas of northern California. Therefore, probably not much oversteepening of the landward slope of the Trench is needed to induce slope failure in the transect area. Alternately, the strength of coupling across the subduction zone may have weakened, thus withdrawing support of the slope. Because the subduction zone appears sufficiently decoupled to facilitate the subduction of all sedi- ment in the Trench, it would not be inconsistent to have slope failure slip planes that reach the top of the subduction zone. If little compressive stress is transmitted across a zone of decoupling, the resistance to listric normal faulting is low.

The products from mass wasting and the toes of large slump blocks were not detected in Trench despite the diverse survey efforts with Seabeam, Deep Tow, and multichannel as well as high-resolution seismic instruments (Aubouin, Stephan, Renard, et al., 1982; Moore et al., 1982; Ladd et al., this volume; T. H. Shipley and G. F. Moore, personal communication, 1983). Abundant slumping was detected in cores, especially the debris flows at Sites 494 and 567, and a general downslope movement of sediment was shown by the abundance of displaced microfossils (McDougall, this volume). Thus the products from collapse and mass wasting that enter the Trench must be subducted along with the other sediment. The basal scarp of the landward slope of the Trench has a very linear trace in the detailed Seabeam maps (Aubouin, Renard, Stephen et al., 1982; T. H. Shipley, personal communication, 1983), indicating dynamic conditions that actively maintain the position of the basal scarp and thus the Trench axis.

The late Neogene tectonics of the landward slope of the Trench are also reflected in the character of San José Canyon. Initial development of the Canyon in the Miocene suggested previously by Ladd et al. 1982 and von Huene et al., (1982) is supported by the multiple sediment fillings of the Canyon (GUA-18A, Back Pocket Plate I) and deep submarine erosion. However, the disappearance of the Canyon as it crosses the lower benches indicates disruption there by tectonism, as first pointed out by McMillen et al., (1982). The abandoned canyon is also disrupted at the benches. Thus the nondisrupted canyon of the late Miocene upslope of the benches is consistent with the general absence of faults in the slope deposits (von Huene et al. , 1982). Across the slope, little Neogene tectonism is indicated by the geophysical data except at the foot of the slope and along the edge of the shelf.

\section{CONCLUSIONS}

Along the Middle America Trench off Guatemala the tectonic histories of rock sequences beneath the present shelf and the landward slope were diverse in the pre-Eocene but have been compatible with the present setting since about the Eocene to late Oligocene. Prior to the Eocene a thick terrigenous sediment sequence accumulated near the base of a continental slope, perhaps now beneath the adjacent continent or along the ancestral Polochic-Montagua transcurrent fault system. In contrast, the rock beneath the present slope sampled during Leg 84 was a highly serpentinized Mesozoic ophiolitic suite rather than imbricated sediment. Some physical properties of these rocks overlap making it difficult to differentiate in geophysical data the altered sediment from the altered ophiolitic rock. A tectonic boundary separates the Cretaceous-Paleocene sedimentary section on 
the shelf from rocks on the slope; each section originated in different environments. Displacement on this boundary juxtaposed these rocks just before or during the tectonic episode that initiated development of the present arc-trench system. This arc-trench system began to form in the Eocene, and by late Oligocene it was structured much like the present system.

The origin of the landward-dipping reflection in the upper slope used by Ladd et al. (1982) as a basis for Neogene accretionary tectonic history is instead from preNeogene tectonism in Mesozoic rock. The reflective sequence at the base of the slope shown by Seely et al. (1974) should be reevaluated by examining the original data or with another survey. The data of Seely et al. (1974) should not be ignored, because they may suggest local accretion, perhaps associated with the collision of a topographic high on the subducting ocean floor, however, only a single seismic line across a nearly $50-\mathrm{km}$-wide area makes more concise interpretation difficult.

This general picture of the Guatemalan margin is defined in greater detail for the Neogene period. The beginning of the Miocene record is marked by the end of the erosion of at least $1 \mathrm{~km}$ of section near the Esso-Petrel drill hole. The coeval conformable section in San José Canyon and east of it indicates an along-strike variability of more than $1 \mathrm{~km}$ in the height of the uplift. The concentration of rapid uplift at the edge of the shelf is suggested by the lack of angular discordance toward the center of the basin. Tectonic uplift and subsidence at the edge of the shelf have continued throughout the Neogene with periodic erosion from the combined processes of uplift and lowered sea level (Seely, 1979). Failure of the lower slope, underlain by an altered ophiolitic basement, produced three rough benches. Such failure suggests weak compressive horizontal stress in the upper plate consistent with the decoupling required for total net subduction of the materials in the Trench. The low strength of the rocks on the slope is probably in part the result of overpressure, as was measured during Leg 84 (von Huene, this volume). The contrast between the somewhat crescent-shaped morphology of the benches and the straight escarpment at the base of the landward slope of the Trench emphasizes the more passive origin of the benches as recognized by Aubouin, Stephan, Renard, et al., (1982), and the dynamic process by which the Trench axis maintains its approximate position. From previous examination of slope sediment structure (von Huene et al., 1982), and from, the stable and well-developed nature of San José Canyon, only the front of the margin and the edge of the shelf were subjected to rapid Neogene tectonism.

The major uncertainty in determining a more complete tectonic history involves the tectonic mechanisms by which the present slope and forearc elements were originally assembled. We suggest two end-member models, which may be tested in future studies.

\section{ACKNOWLEDGMENTS}

We thank our colleagues Jacques Bourgois and Keith Kvenvolden, whose discussions and comments on earlier manuscripts greatly helped us to improve this chapter.

\section{REFERENCES}

Anderson, T. H., and Schmidt, V. A., 1983. The evolution of Middle America and the Gulf of Mexico-Caribbean Sea region during Mesozoic time. Geol. Soc. Am. Bull., 94:941-966.

Aubouin, J., Bourgois, J., and Azéma, J., 1984. A new type of active margin: the convergent-extensional margin, as exemplified by Middle America Trench off Guatemala. Earth Planet. Sci. Lett., 67: 211-218.

Aubouin, J., Stephan, J.-F., Renard, V., Roump, J. and Lonsdale, P., 1982. A SEABEAM survey of the Leg 67 area (Middle America Trench off Guatemala). In Aubouin, J., von Huene, R., et al., Init. Repts. DSDP, 67: Washington (U.S. Govt. Printing Office), 733-738.

Aubouin, J., Stephan, J.-F., Roump, J., and Renard, V., 1982. The Middle America Trench as an example of a subduction zone. Tectonophysics, 86:113-132.

Aubouin, J., von Huene, R., Azéma, J., Coulbourn, W. T., Cowan, D. S., Curiale, J. A., Dengo, C. A., Faas, R. W., Harrison, W., Hesse, R., Ladd, J. W., Muzilev, N., Shiki, T., Thompson, P. R., Westberg, J., 1982. Init. Repts. DSDP, 67: Washington (U.S. Govt. Printing Office).

Coulbourn, W. T., 1982. Stratigraphy and structures of the Middle America Trench. In Aubouin, J., von Huene, R., et al., Init. Repts. $D S D P, 67$ : Washington (U.S. Govt. Printing Office), 691-706.

Ibrahim, A. K., Latham, G. V., and Ladd, J., 1979. Seismic refraction and reflection measurements in the Middle America Trench offshore Guatemala: J. Geophys. Res., 84:5643-5649.

Ladd, J. W., Ibraham, A. K., McMillen, K. J., Latham, G. V., and von Huene, R. E., 1982. Interpretation of seismic reflection data of the Middle America Trench offshore Guatemala. In Aubouin, J., von Huene, R., et al., Init. Repts. DSDP, 67: Washington (U.S. Govt. Printing Office), 675-690.

McMillen, K. J., Enkeboll, R. H., Moore, J. C., Shipley, T. H., and Ladd, J. W., 1982. Sedimentation in different tectonic environments of the Middle America Trench, southern Mexico and Guatemala. In Leggett. J. K., (Eds)., Trench-Forearc Geology, Geol. Soc. London Spec. Publ. 10 (Blackwell) pp. 95-107.

Moore, G. F., Lonsdale, P., and von Huene, R., 1982. Nearbottom observations of the Middle America Trench off Guatemala. In Aubouin, J., von Huene, R., et al., Init. Repts. DSDP, 67: Washington (U.S. Govt. Printing Office), 707-718.

Seely, D., 1979. The evolution of structural highs bordering major fore-arc basins. In Watkins, J. S., Montadert, L., Dickerson, P. W., (Eds.), Geologic and Geophysical Investigations of Continental Margins: Am. Assoc. Pet. Geol. Mem. 29: 245-260.

Seely, D. R., Vail, P. R., and Walton, G. G., 1974. Trench slope model. In Burke, C. A., and Drake, C. L., (Eds.), The Geology of Continental Margins: New York (Springer-Verlag), pp. 249-260.

Shor, G. G., Jr. and Fisher, R. L., 1961. Middle America Trench: Seismic reflection studies. Geol. Soc. Am. Bull., 72:721-730.

Thompson, P. R., 1982. Foraminifers of the Middle America Trench, In Aubouin, J., von Huene, R., et al., Initial Reports of the Deep Sea Drilling Project, v. LXVII, Washington (U.S. Govt. Printing Office).

von Huene, R., Aubouin, J., 1982. Summary-Leg 67, Middle America Trench transect off Guatemala. In Aubouin, J., von Huene, R., et al., Init. Repts. DSDP, 67: Washington (U.S. Govt. Printing Office), 775-796.

von Huene, R., Ladd, J., Norton, I., 1982. Geophysical observations of slope deposits, Middle America Trench off Guatemala, In Aubouin, J., von Huene, R., et al., Init. Repts. DSDP, 67: Washington (U.S. Govt. Printing Office), 719-732. 